\title{
UŽDEGIMINĖ ŽARNŲ LIGA IR PSICHIKOS SUTRIKIMAI
}

\author{
Juozas Rimkus \\ Vilniaus universiteto Medicinos fakultetas
}

Raktažodžiai: uždegiminès žarnų ligos, Krono liga, opinis kolitas, depresija, nerimo sutrikimai.

\section{Santrauka}

Krono liga ir opinis kolitas priklauso uždegiminių žarnu ligų grupei. Lètinè, nenuspejama ligos eiga ir ịprastai jauname amžiuje prasidedantys simptomai blogina gyvenimo kokybę ir didina psichinio distreso riziką, palyginus su bendraja populiacija. Dažniausios psichikos problemos, kurias patiria sergantieji uždegiminėmis žarnų ligomis, yra depresija ir nerimo sutrikimai. Glaudus ryšys tarp nerimo bei depresijos simptomų ir uždegiminès žarnų ligos aiškinamas naujomis teorijomis apie žarnynosmegenų ryšio disfunkciją. Tyrimo tikslas - aptarti sergantiesiems uždegiminėmis žarnų ligomis pasitaikančius psichikos sutrikimus, jų paplitimą, priežastis ir poveiki ligos eigai. Literatūros paieška atlikta PubMed, ScienceDirect, Google Scholar duomenų bazėse. Iš viso atrinkta ir išanalizuota 10 publikacijų, paskelbtų 2013-2020 metu laikotarpiu. Tyrimo rezultatai. Pastaraisiais dešimtmečiais uždegimo reikšmė depresijos atsiradimui buvo intensyviai tyrinejama. Sergantiesiems depresija buvo nustatytas padidejjęs uždegimą skatinančių citokinų ir ūminès fazès uždegimo baltymų bei sumažèjęs priešuždegiminių citokinų, albumino, transferino, a1-antitripsino kiekis. Panašus mediatorių disbalansas stebimas ir sergant uždegiminèmis žarnų ligomis. Depresija siejama su didesne atkryčių rizika ir prastesniu atsaku ị gydymą. Nerimo sutrikimai siejami su didesne operacijų rizika, dažnesniu gydymo režimo nesilaikymu ir suprastėjusia gyvenimo kokybe. Išvados. Psichikos sutrikimai neigiamai veikia uždegiminès žarnų ligos eigą ir baigț. Asmenų, sergančių uždegimine žarnų liga, psichikos sutrikimų gydymas nèra optimizuotas ir šioje srityje reikia daugiau tyrimų.

\section{Ivadas}

Krono liga ir opinis kolitas priklauso uždegiminių žarnu ligų grupei. Šioms ligoms būdingas lètinis uždegimas ir nenuspejama eiga su atkryčiais ir remisijomis. Banguojanti šių ligų eiga, varginantys simptomai, pavyzdžiui, pilvo skausmas, viduriavimas su krauju, svorio kritimas, lètinis nuovar- gis ir komplikacijos, reikalingos chirurginių intervencijų, gali sukelti sunkų neigalumą $[1,2]$. Lètinè eiga ir ịprastai jauname amžiuje (15-30 metų) prasidedantys simptomai, daug recidyvų, aukštas streso lygis, gretutiniai psichikos susirgimai blogina gyvenimo kokybę ir didina psichinio distreso riziką, palyginus su bendraja populiacija [1]. Ryškūs psichiatriniai aspektai sergant uždegiminemis žarnų ligomis žinomi daugelį metų, aprašytas psichikos sutrikimų atsiradimas jau po uždegiminès žarnų ligos diagnozavimo, tačiau šie pacientai nèra rutiniškai tiriami dèl psichikos sutrikimų ir dažniausiai dèl jų nèra gydomi $[2,3]$.

Tyrimo tikslas - aptarti uždegiminėmis žarnų ligomis sergantiems asmenims pasitaikančius psichikos sutrikimus, jų paplitimą, priežastis ir poveikị ligos eigai.

\section{Tyrimo medžiaga ir metodai}

Literatūros paieška atlikta PubMed, ScienceDirect, Google Scholar duomenų bazėse. Naudoti raktažodžiai: inflammatory bowel disease, psychiatric disorders, depression, anxiety. Iš viso atrinkta ir išanalizuota 10 publikacijų, paskelbtų 2013-2020 metų laikotarpiu.

\section{Tyrimo rezultatai}

Epidemiologiniai tyrimai parode, kad dažniausios psichikos problemos, kurias patiria sergantieji uždegiminemis žarnų ligomis, yra depresija ir nerimo sutrikimai [2]. Kanadoje atlikto tyrimo duomenimis, nerimo sutrikimų paplitimas tarp sergančiųjų uždegimine žarnų liga yra 21,1 proc., o depresijos $-25,8$ procento. Šie skaičiai yra didesni, nei bendrosios populiacijos, kurioje generalizuoto nerimo sutrikimo paplitimas per gyvenimą yra 8,7 proc., o depresijos - 11,3 procento [4]. Kitas tyrimas, kuriame buvo naudojama HADS (angl. Hospital Anxiety Depression Scale) skalè, parodè, jog 42,35 proc. pacientu turi nerimo ir 25,8 proc. - depresijos simptomų. Nerimo simptomų paplitimas yra panašus tarp sergančiuju opiniu kolitu (42,15\%) ir Krono liga (42,63\%), tačiau depresijos simptomai dažnesni sergantiesiems Krono liga $(35,2 \%)$, nei opiniu kolitu $(20,5 \%)$. Visiems ị tyrimą itrauktiems pacientams buvo ligos remisija [1]. Kadangi depresijos ir kitų psichikos ligų dažnis tarp sergančiujų žarnų 
uždegimine liga yra didesnis, nei bendrojoje populiacijoje, šių asmenų didesnè ir savižudybès rizika. Vienoje metaanalizèje yra duomenų, jog savižudybès rizika bendrai padideja 1,2 karto, sergant opiniu kolitu - 1,16 karto, o segant Krono liga $-1,36$ karto, palyginus su bendraja populiacija [5]. Nustatyta keletas veiksnių, sukeliančių sergančiųjų uždegimine žarnyno liga depresijos ir nerimo sutrikimus. Moteriškoji lytis, aktyvi liga, socialinès paramos trūkumas, gliukokortikoidu, bet ne TNF-a inhibitoriu, vartojimas susiję su didesne depresijos rizika [2,6]. Moterų, sergančių uždegimine žarnų liga, dažnesnè depresija, nerimo sutrikimai ar bipolinis sutrikimas atspindi bendrosios populiacijos tendencijas. Sergant Krono liga, santykinai daugiau depresija pasireiškia vyrams [3]. Kito tyrimo, kuriame sergantieji Krono liga buvo tiriami naudojant SCL90-R psichinès sveikatos klausimyną, rezultatai parodè, jog gliukokortikoidų vartojimas ir nerūkymas turi teigiamos itakos psichikos sveikatai. Seniau atliktuose tyrimuose taip pat ịrodytas rūkymo ir ekstraintestinių simptomų ryšys, sergant uždegimine žarnų liga [7].

İsitikinta, kad sergantieji uždegimine žarnų liga, daug dažniau nei bendroji populiacija, turi ir nerimo sutrikimų ar depresiją, tačiau vis dar išlieka diskusiju, kad gal tai tik atspindi lètinę šių patologijų eigą, nes psichikos sutrikimų dažnis panašus ir tarp sergančiujų reumatoidiniu artritu, diabetu ir širdies nepakankamumu. Yra faktų, kurie parodo, jog uždegimine žarnų liga sergantys asmenys ypač linkę i psichikos problemas [2]. Glaudus ryšys tarp nerimo bei depresijos simptomų ir uždegiminės žarnų ligos aiškinamas naujomis teorijomis apie žarnyno-smegenų ryšio disfunkciją [1]. Uždegiminès žarnų ligos yra daugiapriežastinès lėtinès ligos su nuolatiniu uždegiminių ir priešuždegiminių mediatorių disbalansu, vyraujant uždegimą skatinantiems veiksniams [1,2]. Per pastaruosius kelis dešimtmečius uždegimo reikšmé depresijos atsiradimui buvo intensyviai tyrinejjama. Sergantiesiems depresija buvo nustatytas padidejęs uždegimą skatinančių citokinų, ypač TNF-a, INF-g, IL-1 ir kt. ir ūminès fazès uždegimo baltymų (haptoglobino, $\mathrm{C}$ reaktyviojo baltymo) kiekis bei sumažèjęs uždegimą slopinančių citokinu (IL-10, TGF-b), albumino, transferino, a1-antitripsino kiekis. Panašus mediatoriu disbalansas stebimas ir sergant uždegiminėmis žarnų ligomis. Cinko trūkumas būdingas ir depresijai, ir uždegiminėms žarnų ligoms, o esant žarnų patologijai, cinko kiekis gali sumažèti ne tik dèl nuolatinio uždegimo būklès, bet ir dẻl malnutricijos ar malabsorbcijos, todèl sergantieji šiomis ligomis labiau linkę i depresiją. Žarnu sienelès pralaidumo padidejjimas ir bakterijų translokaciija - uždegiminių žarnų ligų patogenezei būdinga grandis. Tai padidina lipopolisacharido (LPS) kiekị kraujyje. LPS kiekio ir antikūnų (IgA, IgM) prieš LPS padidèjimas kraujyje randamas ir depresija segančių asmenų kraujyje. Yra preliminariu įrodymų, kad uždegimas žarnyne susijęs ir su bipoliniu sutrikimu. Vienas tyrimas parodè asmenų, sergančių bipoliniu sutrikimu, padidejjusị antikūnų prieš Saccharomyces cerevisiae kiekị kraujyje. Šie antikūnai naudojami kaip žymuo Krono ligos diagnostikai. Tokie atradimai rodo sustiprintą imuninį atsaką į antigenus, kilusius iš žarnyno [2]. Tai vienas iš paaiškinimų, kodèl sergančiųjų uždegimine žarnų liga didesnis psichikos susirgimų, tokių kaip depresija, nerimo sutrikimai, bipolinis sutrikimas ir netgi šizofrenijos (tik sergant Krono liga) dažnis [3].

Psichikos sutrikimai neigiamai veikia uždegiminès žarnu ligos eigą ir baigtį. Depresija siejama su didesne atkryčių rizika ir prastesniu atsaku ị gydymą. Nerimo sutrikimai siejami su didesne operacijų rizika, dažnesniu gydymo režimo nesilaikymu ir suprastejjusia gyvenimo kokybe [3]. Krono liga sergantiems asmenims, turintiems psichikos sutrikimą (depresija arba nerimas), reikšmingai dažniau atliekamos chirurginès intervencijos (24\%), nei asmenims, kurie jo neturi (18\%). Segant opiniu kolitu, gretutiniai psichikos sutrikimai neturejjo reikšmès operacijų kiekiui [8]. Didžioji dalis ị vieną metaanalizę ịtrauktų tyrimų parodè koreliaciją tarp depresinès būklès ir Krono ligos pablogèjimo, t.y. padidèjęs CDAI (Crohn's Disease Activity Index), prastesnis atsakas i biologinę terapiją ar atkryčio rizika, tačiau tik du iš septynių tyrimų parodė ryšį tarp ligos pablogejjimo ir depresijos, sergant opiniu kolitu [9]. Kitas tyrimas parodė, kad sergant uždegimine žarnų liga, depresija neturi poveikio prastesnei baigčiai, o neigiamą ligos dinamiką lemia nerimo sutrikimai [10]. Tokie rezultatai galètų reikšti skirtingą depresijos poveikị uždegiminės žarnų ligos tipams [9]. Abiems ligos tipams su gretutiniais psichikos susirgimais būdingos dažnesnès hospitalizacijos ir didesnè medikamentų naudojimo tikimybė (Krono ligos atveju tai kortikosteroidų, biologinès terapijos ar imunomoduliatorių, opinio kolito atveju - kortikosteroidų) [8]. Nors yra nemažai įrodymų, kad depresija turi neigiamą poveikị uždegiminès žarnų ligos eigai, trūksta žinių apie psichikos sutrikimų poveikị uždegiminès žarnų ligos išsivystymui [2].

Didesnis psichikos ligų paplitimas tarp sergančiųjų uždegimine žarnų liga yra gerai žinomas. Psichikos sutrikimų tyrimas ir gydymas turètų būti integruotas ị kiekvieno paciento, sergančio Krono liga ar opiniu kolitu, priežiūrą, nes gretutiniai psichikos susirgimai blogina ligos eigą. Yra tyrimų, kad kognityvinè elgesio terapija gali pagerinti pacientu gyvenimo kokybę. Uždegimine žarnų liga sergantys pacientai dažnai efektyviai atsako ị gydymą antidepresantais, tačiau, esant svarbiam žarnyno-smegenų ryšiui ir potencialiai žarnų uždegimui tiesiogiai veikiant psichines funkcijas, nereikètų tikètis, kad bendrajai populiacijai tinkantis psichikos ligu gydymas bus taip pat veiksmingas ir šiems pacientams. Gy- 
dymas tokiu atveju nėra optimizuotas ir šioje srityje reikia daugiau tyrimų $[3,5]$.

\section{Išvados}

1. Dažniausios psichikos problemos, kurias patiria sergantieji uždegiminemis žarnų ligomis, yra depresija ir nerimo sutrikimai.

2. Daugeliui lètinių ligų būdingi gretutiniai psichikos sutrikimai, tačiau uždegiminès žarnų ligos atveju svarbi ir nuolatinio uždegimo būsena, žarnyno-smegenų ryšio disfunkcija, bakterijų translokacija ir kt.

3. Psichikos sutrikimai neigiamai veikia uždegiminès žarnų ligos eigą ir baigtị.

\section{Literatūra}

1. Viganò CA, Beltrami MM, Bosi MF, Zanello R, Valtorta M, Maconi G. Alexithymia and psychopathology in patients suffering from inflammatory bowel disease: arising differences and correlations to tailoring therapeutic strategies. Front Psychiatry 2018;9.

https://doi.org/10.3389/fpsyt.2018.00324

2. Nowakowski J, Chrobak AA, Dudek D. Psychiatric illnesses in inflammatory bowel diseases - psychiatric comorbidity and biological underpinnings. Psychiatr Pol 2016;50(6):1157-1166. https://doi.org/10.12740/PP/62382

3. Bernstein CN, Hitchon CA, Walld R, Bolton JM, Sareen J, Walker JR, et al. Increased burden of psychiatric disorders in inflammatory bowel disease. Inflamm Bowel Dis 2019;25(2):360-8. https://doi.org/10.1093/ibd/izy235

4. Byrne G, Rosenfeld G, Leung Y, Qian H, Raudzus J, Nunez C, et al. Prevalence of anxiety and depression in patients with inflammatory bowel disease. Can J Gastroenterol Hepatol 2017;2017. https://doi.org/10.1155/2017/6496727

5. Zhang C, Byrne G, Lee T, Singer J, Giustini D, Bressler B. Incidence of suicide in inflammatory bowel disease: a systematic review and meta-analysis. J Can Assoc Gastroenterol 2018;1(3):107-14.

https://doi.org/10.1093/jcag/gwy025

6. Wilkinson B, Trick L, Knight A, Valton V, Goodhand J, Kennedy NA, et al. Factors associated with depression in people with inflammatory bowel disease: the relationship between active disease and biases in neurocognitive processing. Neurogastroenterol Motil Off J Eur Gastrointest Motil Soc 2019;31(8):e13647. https://doi.org/10.1111/nmo.13647

7. Nazarinasab M, Nematpour S, Seyedian SS, Esfahanian N. Assessing mental health and the relation with variables of de- mographic and clinical in Crohn's disease patients; 2016-2017. J Fam Med Prim Care 2019;8(2):728-32.

https://doi.org/10.4103/jfmpc.jfmpc_236_18

8. Ananthakrishnan AN, Gainer VS, Perez RG, Cai T, Cheng S-C, Savova G, et al. Psychiatric co-morbidity is associated with increased risk of surgery in Crohn's disease. Aliment Pharmacol Ther 2013;37(4):445-54.

https://doi.org/10.1111/apt.12195

9. Alexakis C, Kumar S, Saxena S, Pollok R. Systematic review with meta-analysis: the impact of a depressive state on disease course in adult inflammatory bowel disease. Aliment Pharmacol Ther 2017;46(3):225-35.

https://doi.org/10.1111/apt.14171

10. Narula N, Pinto-Sanchez MI, Calo NC, Ford AC, Bercik P, Reinisch W, et al. Anxiety but not depression predicts poor outcomes in inflammatory bowel disease. Inflamm Bowel Dis 2019 18;25(7):1255-61.

https://doi.org/10.1093/ibd/izy385

\section{INFLAMMATORY BOWEL DISEASE AND PSYCHIATRIC DISORDERS \\ J. Rimkus}

Keywords: inflammatory bowel disease, psychiatric disorders, depression, anxiety.

Summary

Inflammatory bowel disease is comprised of two major disorders: ulcerative colitis and Crohn disease. Chronic, unpredistable course of these diseases and frequent onset in early adulthood usually worsens the quality of life and increase the risk of mental distress when compared to the general population. The close relation between depression, anxiety and inflammatory bowel disease is explained in the emerging theories of "gut-brain axis" dysfunction. Pro inflammatory cytokine and acute phase protein levels are raised in depression patients and the amount of anti-inflamatory cytokines in these patients ais lover than normal. Similar disbalance of these mediators is found in inflammatory bowel disease patients. Psychiatric disorders have a negative effect on the course and outcomes of inflammatory bowel disease. Mental health of patients with Inflammatory bowel disease should be assessed and treated appropriately. Treatment of psychiatric disorders is not optimized for these patients and requires additional studines.

Correspondence to: juozas.rimkus96@gmail.com

Gauta 2021-04-29 